\title{
CORROSION OF RC BEAMS DURING TIME
}

doi: 10.2478/cqpi-2019-0042

Date of submission of the article to the Editor: 18/03/2019

Date of acceptance of the article by the Editor: 13/05/2019

\author{
Yaroslav Blikharskyy ${ }^{1}$ - orcid id: 0000-0002-3374-9195 \\ Roman Khmil ${ }^{2}$ - orcid id: 0000-0001-7578-8750 \\ Zinoviy Blikharskyy ${ }^{3}$ - orcid id: 0000-0002-4823-6405
}

${ }^{1}$ Lviv Polytechnic National University, Department of Highways and Bridges, 6 Karpinskogo Street, 79013, Lviv, Ukraine

${ }^{2}$ Lviv Polytechnic National University, Department of Building Constructions and Bridges, 6 Karpinskogo Street, 79013, Lviv, Ukraine

${ }^{3}$ Czestochowa University of Technology, Faculty of Civil Engineering, Department of Concrete Structures and Geotechnics, 3 Akademicka Street, 42200 Czestochowa, Poland

Abstract: This article presented results of impact corrosion on reinforce concrete beams during time with previous loading. Before testing the $\mathrm{RC}$ beams were loaded by $37 \%$ and $75 \%$ from bearing-capacity load of undamaged corrosion beams. There were tested two types of beams. First type beams were tested under force loading action and second type beams were tested under force loading and corrosion action. As an aggressive environment were used the $10 \%$ solution of sulfuric acid $\mathrm{H}_{2} \mathrm{SO}_{4}$. Such environment takes place in separate chemical manufactures, galvanic workshops, flue pipes of thermal power plants. The results of experimental studies have established that the effect of the aggressive environment with simultaneous loading significantly impairs the stress-strain state of reinforced concrete beams. Bearing capacity due to the yielding of reinforcement bars for specimens with the simultaneous action of aggressive environment and previous loading of $37 \%$ and $75 \%$ takes place on $51 . .53$ and $58 . .60$ days. The destruction of these specimens, by crushing compressive concrete, at previous loading $37 \%$ occurred after $75 \ldots 79$ and at previous loading $75 \%$ - after $79 \ldots 88$ days. The history loading does not impact significantly on beams failure, on finite deflections and timing exhaustion bearing capacity since the start of the simultaneous action of aggressive environment and loading.

Keywords: reinforce concrete beam, corrosion, aggressive environment.

\section{INTRODUCTION}

Reinforced concrete constructions are one of the most popular materials for the present time and its study is constantly engaged (Bobalo, et al., 2018; Fadhil et al., 2018; Khmil et al., 2018; Koz, 2017; Al Saffar et al., 2019; Sobol, el al., 2014). Often, as a result of increasing design requirements or increasing of seismic resistance (Kramarchuk et al., 2018), such structures need to be repair and strengthen (Brózda 
et al., 2017; Blikharskyy, et al., 2018; Krainskyi et al., 2018; Vegera et al., 2018; Tayeh et al., 2013).

Reinforced concrete constructions of buildings and structures with aggressive environment are exploited under difficult conditions (Selejdak et al., 2014). In the stress-deformed state of such structures, in addition to the type of load affected by corrosion processes occurring both in concrete and in reinforcement (Blikharskyy et al., 2019; Blikhars'kyi and Obukh, 2018; Zhang et al., 2014). Frequently, concrete structures are operated without the direct influence of an aggressive environment. However, due to emergency situations, malfunctions of technological equipment of chemical production, chemically active substances fall on the surface of reinforced concrete structures, causing concrete and reinforcement corrosion (Al-Sherrawi et al., 2018; Selejdak et al., 2018). In order to study the features of a change in the stressstrain state in such conditions, the following experimental studies were performed.

\section{RESEARCH METHODOLOGY}

For the experimental research there were made three series of reinforced concrete beams by the sizes of $2100 \times 200 \times 100 \mathrm{~mm}$ with stretched reinforcement $2 \varnothing 14$ bars A400C accordingly, and in compressed area $2 \varnothing 5 \mathrm{Bp}-1$. The transverse reinforcement was $\varnothing 5$ bars Bp-1 with step of $75-100 \mathrm{~mm}$. The concrete mix of series is accepted with fine aggregate $10-20 \mathrm{~mm}$. The concrete compressed strength made $44 \mathrm{MPa}$. In general, 6 beams (two specimens in each series) were tested.

Firstly, in order to define bearing capacity of undamaged experimental beams $\left(M_{\max }\right)$, they were tested by 4-point bending till they failure. Applying of a short term load was achieved with two concentrated forces in one-third of their span. Thus, deflection, presence and evolution of cracks, deformations of concrete and reinforcement were noted. Ultimate limit state (ULS) of beams passed due to the reinforcement's yield in the stretched area with the following failure by crushing of the compressed edge of concrete.

For the research of effect of simultaneous acting of the corrosive environment and load on bearing capacity, two beams of each series was investigated, while one of the beams of each series were subjected only by corrosive environment. The beams were marked BD. Schemes of special equipment on which the experimental research was carried out presented on Fig. 1.

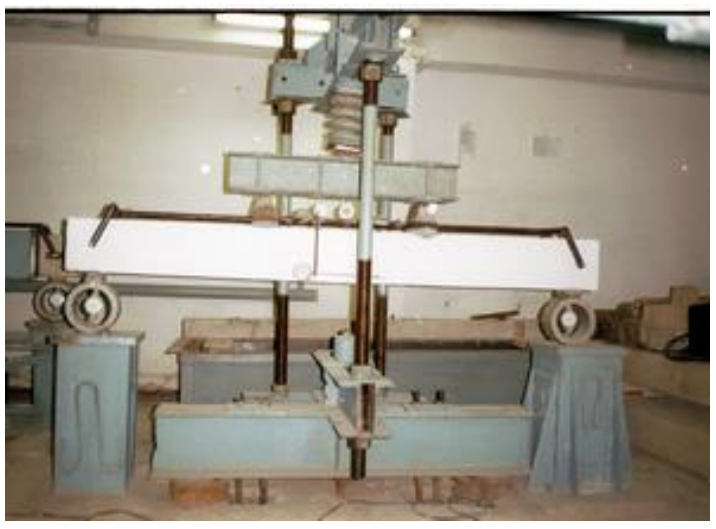

a)

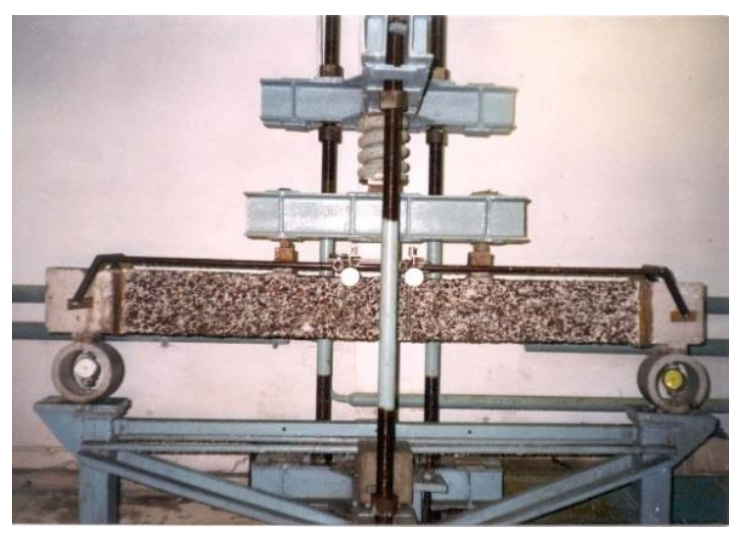

b)

Fig. 1. Equipment for experimental testing of beams for a long-term load effect (a) and for a simultaneous action of long-term load effect and aggressive environment (b) 
Beams undergoing a simultaneous action of the corrosive environment and loading were previously loaded to a level $37 \%$ (specimens BD-2.3, BD-2.4) and to a level $75 \%$ (specimens BD-2.5, BD-2.6) from bearing capacity (ULS) of undamaged beams (without previous loading and without corrosion). Beams under corrosion action marked in the end of name with "c". The loading's value was controlled by special ring-balance dynamometers. As corrosive environment of $10 \%$ solution of sulphuric acid $\mathrm{H}_{2} \mathrm{SO}_{4}$ was used. Such environments occur in separate chemical productions, electroplating shops, smoke pipes etc. High concentration of solution also resolved for rather small period simulation effect of simultaneous acting of the corrosive environment and loading.

A solution of acid was poured into a specially fixed bath on the beams, treated with anticorrosive coatings. There was constant control over the concentration of aggressive environment. When the concentration of acid is reduced by more than $1 \%$, the solution is changed.

During testing deformation of the compression of concrete was measured and with the help of specially developed technique the deformations of the upper fibers of the concrete were determined. The deflections of the beams were measured using the mechanical gauges fixed on the special steel frame, fixed at the neutral axis of the beams above the supports. The error in this method of measuring deflections does not exceed $1 \%$. In addition, on the stretched reinforcing bars were fixed special steel holders, which stand outside the baths and allowed to measure deformations of bars.

\section{RESULTS OF THE EXPERIMENTAL STUDY}

$\mathrm{RC}$ beams were in aggressive environment up to 50 days (BD-2.5-0.75c with previous loading $75 \%$ ) and up to 64 days (BD-2.5-0.37c with previous loading 37\%) with an increase in the. The increasing of compression deformation of concrete for specimens with previous loading $75 \%$ were from $\varepsilon_{b 0}=140 \times 10^{-5}$ to $\varepsilon_{b}=300 \times 10^{-5}$ and for ones with previous loading $37 \%$ they were from $\varepsilon_{b 0}=70 \times 10^{-5}$ to $\varepsilon_{b}=180 \times 10^{-5}$. The deflection of beams increased nonlinearly with a sharp increase after the 50th and 64th day. This state indicates the achievement of stresses in the tension rebar's at the beginning of the yield stress, that we have interpreted as the bearing capacity of the tested beam. Physical destruction of the beams with previous loading $75 \%$ has occurred by crushing of the compressed concrete and was reached after 60 days and after 79 days for beams with previous loading 37\%. The physical destruction of beam BD-2.4$0.37 \mathrm{c}$ has occurred from shear. The results were showed in the Fig. 2-5.

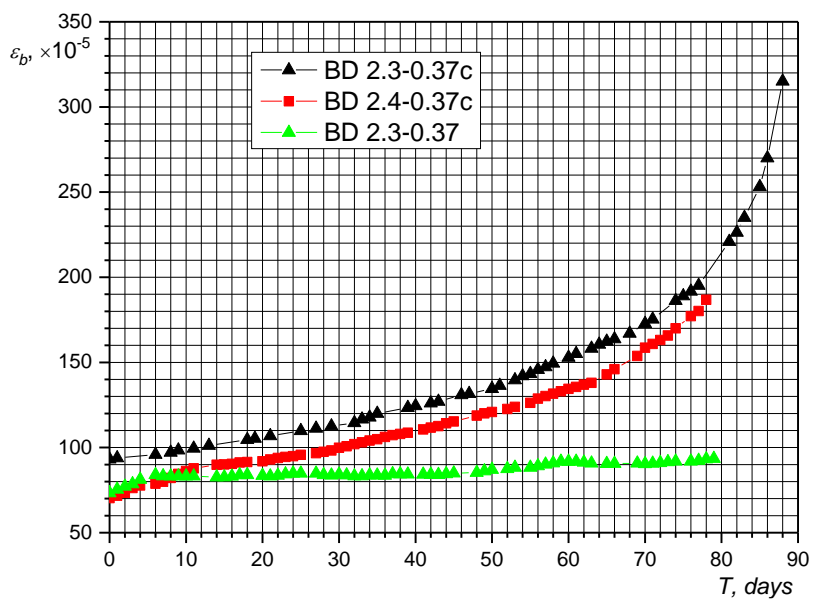

Fig. 2. Compression deformation of concrete for load level $0,37 \mathrm{M}_{\max }$ during the time 


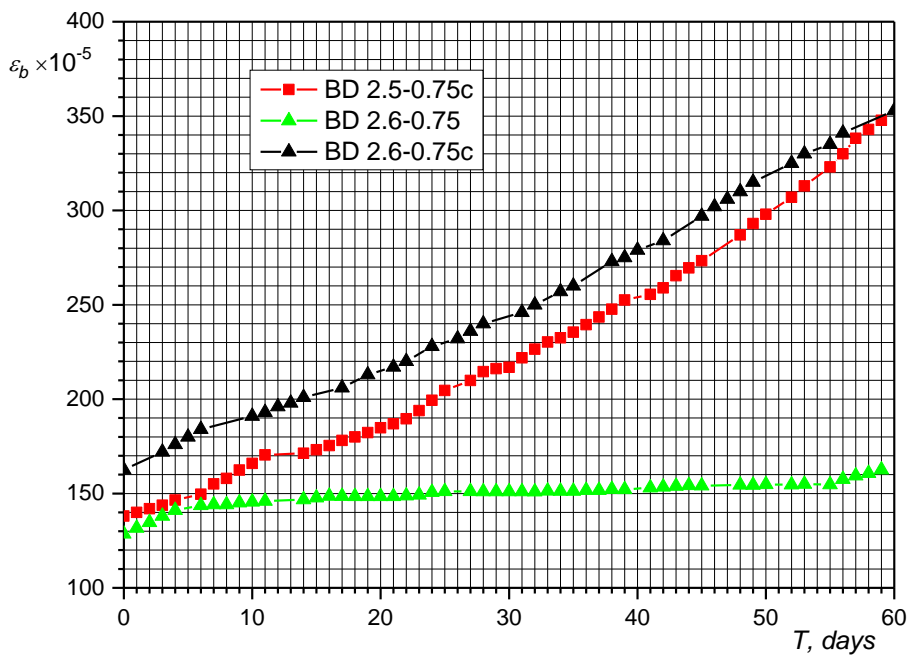

Fig. 3. Compression deformation of concrete for load level $0,75 \mathrm{M}_{\mathrm{max}}$ during the time

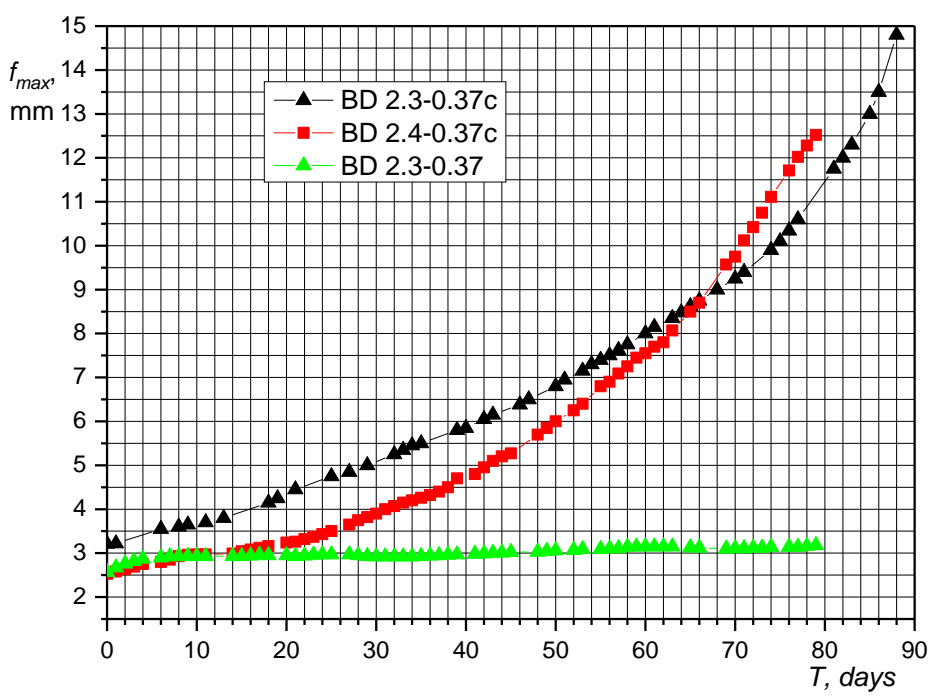

Fig. 4. The maximum displacement of $\mathrm{RC}$ beams for load level $0,37 \mathrm{M}_{\max }$ during the time

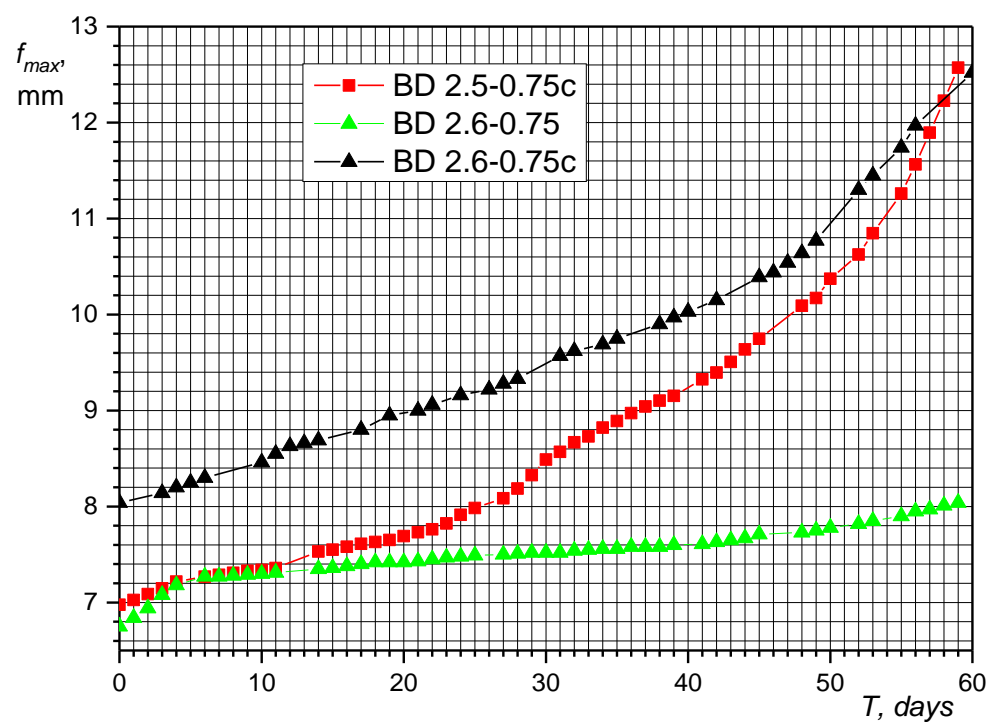

Fig. 5. The maximum displacement of $\mathrm{RC}$ beams for load level $0,75 \mathrm{M}$ max during the time 
The overall view of beams destruction can be seen in Fig. 6, 7. It should be noted that the corrosion of concrete passed from the moment of filling of fixed on the beams of baths with acid solution. This is evidenced by the white precipitate, which was constantly formed on the surface of beams. As a result of the acid reaction with the components of the concrete is the appearance of gypsum $\left(\mathrm{CaSO}_{4} \cdot 2 \mathrm{H}_{2} \mathrm{O}\right)$ :

$$
\mathrm{Ca}(\mathrm{OH})_{2}+\mathrm{H}_{2} \mathrm{SO}_{4}=\mathrm{CaSO}_{4} \cdot 2 \mathrm{H}_{2} \mathrm{O}
$$

Quartz sand and granite crumb practically did not affect corrosion and fell from the surface of the beam as corrosion of the cement stone. The corrosion of concrete beams led to a decrease in the size of the cross section of beams, which was the main reason for the growth of deflections and deformations of compressed concrete.

$\mathrm{RC}$ beams, which were under loading without corrosion influence, had a slight increase in deflections from 6.8 to $8 \mathrm{~mm}$ for BD-2.6-0.75 (with previous loading 75\%) and from 2.6 to $3.2 \mathrm{~mm}$ for BD-2.3-0.37 (with previous loading 37\%).

The growth of the deformation of the concrete in the compressed zone was also small: $\Delta \varepsilon_{b}=30 \times 10^{-5}$ for the previous loading $75 \%$ and $\Delta \varepsilon_{b}=20 \times 10^{-5}$ for previous loading $37 \%$. A significant increase of concrete's deformations of beams under the simultaneous action of corrosion and preloading is $\Delta \varepsilon_{b}=160 \times 10^{-5}$ (previous loading $75 \%$, specimen $\mathrm{BD}-2.5-0.75 \mathrm{c}$ ) and $\Delta \varepsilon_{b}=117 \times 10^{-5}$ (previous loading $37 \%$, specimen BD-2.4-0.37c).

Thus the presence of corrosive environment significantly affects the stress-strain state of beams under load.

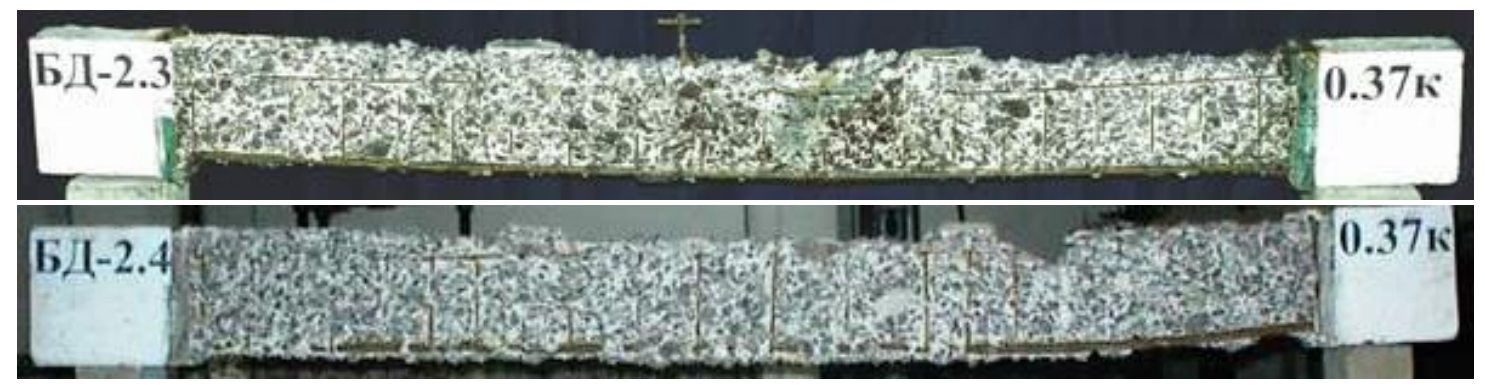

Fig. 6. The overall view of failure of experiment beams of level $0,37 \mathrm{Mmax}$

At the next stage of experimental studies on beams that were under loading without aggressive environment, were mounted baths and filled the same $10 \%$ solution of sulfuric acid $\mathrm{H}_{2} \mathrm{SO}_{4}$. The increase of deflections when aggressive environment appeared was more intensive. However, in comparison with the beams on which the aggressive environment acted from the beginning of loading, the intensity of the increase of deflections was less (Figure 4,5). The type of destruction of the beams was similar. After 50 days (at a level of $0.75 \mathrm{M}_{\max }$ ) and after 70 days (at a level of 0.37 $M_{\max }$ ), a sharp increase of deflections was observed, indicating the achievement of yield stresses in the tension bars. In the next time the physical destruction of the beams was appeared due to the fragmentation of the compressed concrete at 59 day at a level of $0.75 \mathrm{M}_{\max }(\mathrm{BD}-2.6-0.75 \mathrm{c})$ and at 88 day at a level of $0.37 \mathrm{M}_{\max }$ (BD-2.3$0.37 \mathrm{c}$ ). In this case, the final deflections of the beams were $12.38 \mathrm{~mm}$ at a level of $0.75 \mathrm{M}_{\max }$ and were practically equal to the maximum deflection of the beams on which the aggressive environment acted from the moment of loading. The final deflection of the beam at a level of $0,37 \mathrm{M}_{\max }(\mathrm{BD}-2 \cdot 3-0.37 \mathrm{c}$ ) was $14,8 \mathrm{~mm}$, which 
exceeds the value of the final deflection of the beam, on which the aggressive environment acted immediately from the moment of loading (BD-2.4-0,37c) by $18.2 \%$. This can be explained by the fact that the bearing capacity of the beam with a smaller bend of BD-2.4-0.37c was exhausted from shear, so the deflection did not reach the maximum value.

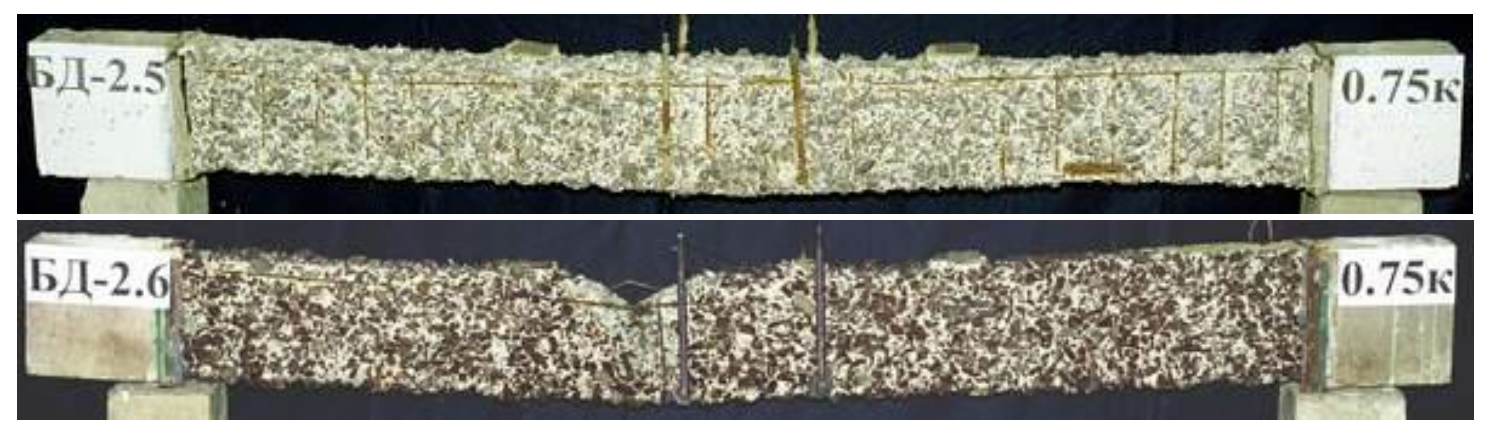

Fig. 7. The overall view of failure of experiment beams of level $0,75 \mathrm{Mmax}$

Table 2.

Experiment results

\begin{tabular}{|c|c|c|c|c|c|c|c|c|c|}
\hline \multirow{3}{*}{ Specimens } & \multicolumn{3}{|c|}{$\begin{array}{c}\text { Before influence } \\
\left(\mathrm{H}_{2} \mathrm{SO}_{4}\right)\end{array}$} & \multicolumn{6}{|c|}{ During influence $\left(\mathrm{H}_{2} \mathrm{SO}_{4}\right)$} \\
\hline & \multirow[b]{2}{*}{$\begin{array}{l}\text { Displ., } \\
\text { mm }\end{array}$} & \multirow[b]{2}{*}{$\begin{array}{l}\text { Def., } \\
\times 10^{-5}\end{array}$} & \multirow[b]{2}{*}{$\begin{array}{l}\text { Area, } \\
\mathrm{cm}^{2}\end{array}$} & \multirow[b]{2}{*}{$\begin{array}{l}\text { Displ., } \\
\text { mm }\end{array}$} & \multirow[b]{2}{*}{$\begin{array}{l}\text { Def., } \\
\times 10^{-5}\end{array}$} & \multirow[b]{2}{*}{$\begin{array}{l}\text { Area, } \\
\mathrm{cm}^{2}\end{array}$} & \multicolumn{2}{|c|}{ Time, days } & \multirow[b]{2}{*}{$\begin{array}{c}\text { Type of } \\
\text { destructio } \\
n\end{array}$} \\
\hline & & & & & & & $\begin{array}{l}\text { Rebars } \\
\text { yield }\end{array}$ & $\begin{array}{c}\text { Conc- } \\
\text { rete } \\
\text { failure }\end{array}$ & \\
\hline $\begin{array}{c}\text { BD-2.3- } \\
0.37 c\end{array}$ & 0,6 & 20,3 & 205 & 14,80 & 315 & 87 & 79 & 88 & bending \\
\hline $\begin{array}{c}\text { BD-2.4- } \\
0.37 \mathrm{c}\end{array}$ & 0 & 0 & 206 & 12,52 & 187 & 82 & 75 & 79 & shear \\
\hline $\begin{array}{c}\text { BD-2.5- } \\
0.75 c\end{array}$ & 0 & 0 & 201 & 12,50 & 348 & 104,3 & 53 & 59 & bending \\
\hline $\begin{array}{c}\text { BD-2.6- } \\
0.75 c\end{array}$ & 1,1 & 34 & 203 & 12,38 & 353 & 107.2 & 51 & 60 & bending \\
\hline
\end{tabular}

Notes:

"Displ." It's means the displacement of RC beams during the time.

"Def." it's means the deformation of compressive concrete during the time.

As we see from the table 2 the exhaustion bearing capacity due to the yielding of reinforcement bars specimens BD-2.3-0.37c and BD-2.4-0,37c loaded to a level of $37 \%$ from load-carrying capacity of ULS of control beams takes place on 51 and 53 days, for beams loaded to a level of 75\% (BD-2.5-0.75c and BD-2.6-0.75c) takes place on 75 and 79 days.

The failure of the beams, by crushing compressive concrete took place later on 58 ... 60-day, 79 ... 88-day loaded levels at $75 \%$ and $37 \%$, respectively.

At the same time, in the beam of the BD-2.4-0.37c, the destruction went through from shear (Fig. 2). The reason for this destruction was corrosion of practically all transverse bars.

So from these experimental studies we can conclude that history loading does not impact significantly on beams failure, on finite deflections and timing exhaustion bearing capacity since the start of the simultaneous action of aggressive environment and loading. 


\section{CONCLUSIONS}

1. The performed experimental researches have established that the action of the aggressive environment with simultaneous loading significantly impairs the stressstrain state of reinforced concrete beams.

2. The deformation of concrete and deflection is more intense than in the beams, which only the load is applied. This is due to the reduction of the area in $1.9 \ldots 2.5$ times after the impact of corrosion.

3. Bearing capacity due to the yielding of reinforcement bars for specimens with the simultaneous action of aggressive environment and previous loading of $37 \%$ and $75 \%$ takes place on $51 \ldots 53$ and $58 \ldots 60$ days. The destruction of these specimens, by crushing compressive concrete, at previous loading $37 \%$ occurred after $75 \ldots 79$ and at previous loading $75 \%$ - after $79 \ldots 88$ days.

4. The history loading does not impact significantly on beams failure, on finite deflections and timing exhaustion bearing capacity since the start of the simultaneous action of aggressive environment and loading.

\section{References}

Al Saffar, D., Alsaad, A., Tayeh, B. 2019. Effect of Internal Curing on Behavior of High Performance Concrete: An Overview. Case Studies in Construction Materials, 10. 10.1016/j.cscm.2019.e00229.

Al-Sherrawi, M., Lyashenko, V., Edaan, E., Sotnik, L., 2018. Corrosion as a Source of Destruction in Construction. International Journal of Civil Engineering and Technology. 9. 306-314.

Blikhars'kyi, Z. Ya., Obukh, Y. 2018. Influence of the Mechanical and Corrosion Defects on the Strength of Thermally Hardened Reinforcement of 35GS Steel. Materials Science. 54. 10.1007/s11003-018-0183-2.

Blikharskyy, Y., Khmil, R., Blikharskyy, Z., 2018. Research of RC Columns Strengthened by Carbon FRP Under Loading, Matec Web of Conferences, 174, 18, DOI: 10.1051/matecconf/201817404017

Blikharskyy, Z., Vegera, P., Vashkevych, R., Shnal, T., 2018. Fracture toughness of $R C$ beams on the shear, strengthening by FRCM system. MATEC Web of Conferences. 183. 02009. 10.1051/matecconf/201818302009.

Blikharskyy, Z., Selejdak, J., Blikharskyy, Y., Khmil, Roman., 2019. Corrosion of Reinforce Bars in RC Constructions. System Safety: Human - Technical Facility Environment. 1. 277-283. 10.2478/czoto-2019-0036.

Bobalo, T., Blikharskyy, Y., Vashkevich, R., Volynets, M., 2018. Bearing capacity of $R C$ beams reinforced with high strength rebars and steel plate. Matec Web of Conferences, 230, 02003, DOI: 10.1051/matecconf/201823002003.

Brózda, K., Selejdak, J., Koteš, P., 2017. The Analysis of Beam Reinforced with FRP Bars in Bending, Procedia Engineering, 192, 64-68, DOI: 10.1016/j.proeng.2017.06.011

Fadhil, B., Al-Rumaithi, A., Al-Sherrawi, M. 2018. Properties of Reactive Powder Concrete with Different Types of Cement. International Journal of Civil Engineering and Technology. 9. 1313-1321.

Khmil, R., Tytarenko R., Blikharskyy, Y., Vegera, P., 2018. Development of the procedure for the estimation of reliability of reinforced concrete beams, 
strengthened by building up the stretched reinforcing bars under load, EasternEuropean Journal of Enterprise Technologies, 5/7 (95), DOI: 10.15587/17294061.2018.142750.

Kos, Ž., Gotal Dmitrović, L., Klimenko, E., 2017. Developing a Model of a Strain (Deformation) of a Damaged Reinforced Concrete Pillar in Relation to a Linear Load Capacity, Technical Journal, 11(4), 150-154, (https://hrcak.srce.hr/190990)

Krainskyi, P., Blikharskyy, Y., Khmil, R., Blikharskyy, Z., 2018. Experimental Study of the Srengthening Effect of Reinforced Concrete Columns Jacketed Under Service Load Level, Matec Web of Conferences, 183, 1-5, DOI: 10.1051/matecconf/201818302008

Krainskyi, P., Blikharskyy, Y., Khmil, R., Vegera, P., 2018. Influence of loading level on the bearing capacity of RC columns strengthened by jacketing. Matec Web of Conferences, 230, 02013, DOI: 10.1051/matecconf/201823002013.

Kramarchuk, A., Ilnytskyy, B., Lytvyniak, O., Grabowski, A., 2019. The increase of seismic stability for existing industrial buildings. AIP Conference Proceedings. 2077. 020029. 10.1063/1.5091890.

Selejdak, J., Khmil R., Blikharskyy, Z., 2018. The Influence of Simultaneous Action of the Aggressive Environment and Loading on Strength of RC Beams, Matec Web of Conference, 183, 1-6, DOI: 10.1051/matecconf/201818302002

Selejdak, J., Ulewicz, R., Ingaldi, M., 2014. The Evaluation of the Use of a Device for Producing Metal Elements Applied in Civil Engineering, 23 ${ }^{\text {rd }}$ International Conference on Metallurgy and Materials, Ostrava, Tanger, 1882-1888

Sobol, K., Blikharskyy, Z., Petrovska, N., Terly`a, V., 2014. Analysis of Structure Formation Peculiarities during Hydration of Oil-Well Cement with Zeolitic Tuff and Metakaolin Additives, Chemistry \& Chemical Technology 8(4), 461-465 DOI: 10.23939/chcht08.04.461

Tayeh, B., Bakar, B.H., Megat J., Megat A., Voo, Y. 2013. Evaluation of Bond Strength between Normal Concrete Substrate and Ultra High Performance Fiber Concrete as a Repair Material. Procedia Engineering. 54. 554-563. 10.1016/j.proeng.2013.03.050.

Vegera, P., Vashkevych, R., Blikharskyy, Z., 2018. Fracture Toughness of RC Beams With Different Shear Span, Matec Web of Conferences, 174, 1-8, DOI: $10.1051 /$ matecconf/201817402021

Zhang, Q., Mol'kov, Y.V., Sobko, Y.M., Blikhars'kyi, Y.Z., Khmil, R.E., 2015. Specific Fracture Energy of Thermally Hardened Reinforcement, Materials Science, 50(6), 824-829 